MaPan : Jurnal Matematika dan Pembelajaran

p-ISSN: 2354-6883 ; e-ISSN: 2581-172X

Volume 8, No 1, June 2020 (125-139)

DOI: https://doi.org/10.24252/mapan.2020v8n1a10

\title{
EFFECTIVENESS OF DISCOVERY LEARNING MODEL ON STUDENTS' MATHEMATICAL PROBLEM SOLVING ABILITY
}

\author{
Fitriani Nur1), Thamrin Tayeb2), Virginia Meyka Widayanti ${ }^{33}$, A.Sriyanti'), \\ Nurhidayah ${ }^{5}$ \\ 1,2,3,4Faculty of Tarbiyah dan Teacher Training UIN Alauddin Makassar \\ ${ }^{5}$ Faculty of Teknik, UNANDA Palopo \\ 1,2,3,4Jl. H.M. Yasin Limpo No. 36 Samata-Gowa, 5Jl. Pulang Haji Daud No. 4 Palopo \\ E-mail: fitrianinur@uin-alauddin.ac.id'1), thamrin.tayeb@uin-alauddin.ac.id²), \\ virginiameykawidayanti@gmail.com ${ }^{3}$, a.sriyanti@uin-alauddin.ac.id ${ }^{4}$, \\ hidayah03@gmail.com5
}

Received May, 13 2020; Revised June, 24 2020; Accepted June, 252020

\begin{abstract}
:
This study aims to determine the application of discovery learning model on students mathematical problem solving abilities. This research is experimental research with a quasi experimental design. The population in this study were all students of grade VII SMPN 4 Sungguminasa with grade VII.A as samples an experimental class and grade VII.C as a control class. The research instruments used a test to solve mathematical problems. Data analysis techniques were descriptive statistical analysis and inferential statistical analysis. Based on the results of the analysis, it was found that the application of discovery learning model is effective on students' mathematical problem solving abilities.
\end{abstract}

Keywords: Discovery Learning Model, Problem Solving Ability

\section{EFEKTIVITAS PENERAPAN MODEL PEMBELAJARAN DISCOVERY LEARNING TERHADAP KEMAMPUAN PEMECAHAN MASALAH MATEMATIKA SISWA}

\begin{abstract}
Abstrak:
Penelitian ini bertujuan untuk mengetahui penerapan model pembelajaran discovery learning terhadap kemampuan pemecahan masalah matematika siswa. Penelitian ini merupakan jenis penelitian eksperimen dengan desain penelitian yaitu quasi eksperimental design. Populasi pada penelitian ini yaitu seluruh siswa kelas VII SMPN 4 Sungguminasa dengan sampel pada kelas VII.A sebagai kelas eksperimen dan kelas VII.C sebagai kelas kontrol. Instrumen dalam penelitian ini adalah tes kemampuan pemecahan masalah matematika. Teknik analisis data menggunakan analisis statistik deskriptif dan analisis statistik inferensial. Berdasarkan hasil analisis diperoleh bahwa penerapan model pembelajaran discovery learning efektif terhadap kemampuan pemecahan masalah matematika siswa.
\end{abstract}

Kata kunci: Model Pembelajaran Discovery Learning, Kemampuan Pemecahan Masalah Matematika

Copyright $@$ 2020, MaPan : Jurnal Matematika dan Pembelajaran 
How to Cite: Nur, F., Tayeb, T., Widayanti, V. M., Sriyanti, A., \& Nurhidayah. (2020). Effectiveness of Discovery Learning Model on Students' Mathematical Problem Solving Ability. MaPan: Jurnal Matematika dan Pembelajaran, 8(1), 125-139. https://doi.org/10.24252/mapan.2020v8n1a10.

$\mathrm{E}$ ducation, which is derived from the word educate (teaching) or means giving an increase (to elicit, to give rise to) and improve (to evolve, to develop) (Mustofa, 2015: 6). In addition, Sanjaya (2017: 13) expressed his opinion about education, namely: (a) education is life; (b) education is any learning experience that takes place in all environments and throughout life; (c) education takes place in all environments, both created explicitly for education and existing in oneself; (d) education takes place in all forms, patterns, and institutions. Therefore, ongoing education during human life is very important to support so that humans can live more decent lives.

The purpose of education is to cover a picture of good, noble, appropriate, correct, and beautiful values for life. Moreover, the educational goals stated by Tirtarahardja (2010: 38) has two functions, namely giving direction to all educational activities and is something that all educational activities want to achieve. The goal will be able to show the direction of a business, while the direction shows the path that must be taken from the present situation to the next situation if there are obstacles or problems in the implementation of education. Research conducted by (Ketonen, Dietrich, Moeller, Salmela-Aro, \& Lonka, 2018: 25) explained that students who on an average level, perceived the educational goals as autonomously motivated, also tended to experience positive emotions more often.

Along with the times, the demands on life have also been growing rapidly. So, to be able to deal with it, education is needed, both in the form of formal and informal education. According to the Minister of National Education in Hidayat (2011: 8), contents of the educational competency standards of Junior High School/ Islamic Junior High School students, among others, students can think logically, analytically, critically and creatively, and can work together. The alumni of Junior High School/ Islamic Junior High School students must have high-level thinking skills that can be applied in solving complex everyday problems (Hidayat, 2011: 8). Therefore, they can be more independent in solving the problems they face. 
One important component in the world of education is the curriculum. According to Susanto (2013: 183), mathematics is one of the fields of the study found in the curriculum and is taught at all levels of education, starting at the level of elementary school education to college. Even in kindergarten, mathematics is taught informally. In recent years, mathematics has become one of the most highlighted subjects by all of the elements, including teachers, parents, and students. Besides being a determinant of mathematics in passing the national exam, it is also considered as one of the subjects that is difficult for students to master. Even education experts and mathematics education experts have spent years trying ways that can be taken so that students can master mathematics. According to the research done by Shaikh \& Daudpota (2019: 26), several other factors that make mathematics difficult to master and always considered complicated, such as no parental support, and inconsistent assessment, and weak mathematics concepts.

Most people who talk about mathematics will assume that mathematics is a difficult subject and has a difficult problem to solve. Mathematics, in general, is a branch of science that is very close to the reality of human life. Besides being useful in daily life, mathematics is also useful in various other fields such as science, commerce, and industry because mathematics is not just the science of arithmetic. Mathematics provides power, a brief and unambiguous communication tool, and functions as a tool to describe and predict (Uno, 2008: 129). Thus mathematics can be defined as a field of science that is a tool of thought, communication, a tool to solve various practical problems, the elements of logic and intuition, analysis and construction, generality and individuality, and has branches including arithmetic, algebra, geometry, and analysis. Therefore, the purpose of education is to provide knowledge and experience and help to solve the problems related to everyday life and sometimes things that are difficult to obtain immediately. In mathematics, such matters are usually in the form of solving mathematical problems that contain non-routine problems that are more directed to arrive at the correct procedure and require deeper thinking.

The ability to solve mathematical problems is one important aspect that must be possessed by students to develop the abilities that exist in themselves. As what is defined by Anderson and Krathwohl in Rahman \& Ahmar (2016) that problem solving through the process of learning mathematics can help students improve and develop their abilities in aspects of the application, analysis, synthesis, and evaluation. 
Simamora, Saragih, \& Siregar (2019: 62) expressed that students' mathematical problem solving ability can be defined as students' ability to understand problems, plan problem solving strategies, carry out selected strategies of completion, and re-examine problem solving. Likewise, another opinion related to problem solving, according to Hulukati, Zakiyah, \& Rustam (2018: 212) problem solving is a process to apply the previously acquired knowledge to new or unusual situations.

Problem solving ability of students is still relatively low. Based on the results of research conducted by Priya (2017: 41), it was revealed that the mastery of problem solving skills, among the junior high school students are still at moderate level. As what Utami \& Wutsqa (2017: 173) illustrated that students' problem solving abilities are very low, because students have difficulty mastering the material being studied, they have not been able to understand concepts to solve problem solving. Meanwhile, based on research finding of Akbar, Hamid, Bernard, \& Sugandi (2018: 152), it was revealed that the factors that cause students to make mistakes in solving mathematical problem solving problems are students' lack of understanding in interpreting information on problems in the form of mathematical operations.

There are two kinds of difficulties experienced by students in the process of solving mathematical problems, according to Fahmi, Sinaga, \& Rajagukguk (2019: 168), namely conceptual difficulties and procedural difficulties. In the results of his research, he explained further about the two kinds of difficulties. The conceptual difficulty is a difficulty in applying operation concepts to calculate integers and fractions to solve problems, and the procedural difficulty is the difficulty in presenting steps in solving problems and difficulty in arranging strategies to solve problems effectively and efficiently. Hence, in learning mathematics, educators need to pay more attention to the difficulties experienced by students.

Mathematics learning conducted by teachers tends to seem monotonous so that it has not been able to improve student mathematics learning outcomes instead, for example, in grade VII students of SMPN 4 Sungguminasa, Gowa Regency, where most students have low learning outcomes, especially in mathematics learning. According to the results of interviews conducted on July 24, 2018, with some students, it can be concluded that they consider mathematics to be a boring and tense subject. Meanwhile, by the results of interviews with teachers in mathematics, it is known that some students are more interested in solving routine problems than non-routine problems. 
Suppose that a routine problem is known $\mathrm{n}(\mathrm{S})=30, \mathrm{n}(\mathrm{A})=15, \mathrm{n}(\mathrm{B})=10$ and $\mathrm{n}(\mathrm{A} \cup \mathrm{B})^{\mathrm{C}}=7$, determine $\mathrm{n}(\mathrm{A} \cap \mathrm{B})$ and non-routine problems, namely residents of RT 05 consisting of 30 people, apparently 15 people subscribe to magazines, 10 people subscribe to newspapers, and 7 people do not subscribe to both, so how many residents of RT 05 subscribe to newspapers and magazines. Based on these two problems, students are more interested in solving the first problem than the second problem. This can occur because the teacher only gives formulas/patterns, examples of related questions, and only gives exercises. Meanwhile, to solve non-routine problems, mastery of concepts is needed.

It seems that the teacher needs to pay attention to the problem given that one of the students' abilities that needs to be improved is the problem-solving ability, especially in solving mathematical problems. The seventh-grade mathematics teacher of SMPN 4 Sungguminasa, Gowa Regency, also said that the learning outcomes of grade VII students on mathematics were still very low. It can be seen from the cognitive learning outcomes of students who are still under the MCC (Minimum completeness criteria). According to the seventhgrade mathematics teacher of SMPN 4 Sungguminasa, Gowa Regency, there were about $85 \%$ of students or 81 out of 96 students whose learning outcomes had not yet reached the MCC score of 75 (Interview results, July 24, 2018, at 10:00 a.m. WITA' Central Indonesian Time'). Such conditions encourage teachers to strive to optimize learning done to improve students' mathematical problem solving abilities.

One effort that can be taken in terms of improving students' mathematical problem solving abilities is by applying learning models that seem quite interesting and able to improve student mathematics learning outcomes. The learning model that can be used to improve student mathematics learning outcomes is the discovery learning model. This was confirmed by several previous studies, including research conducted by Sitinjak, Murni, \& Hutapea (2016) stated that during the mathematics learning process, discovery learning could improve the learning process and improve student learning outcomes in mathematics. The results of research conducted by Sarnawiah \& Yensy (2019) cited that the learning activities of students during mathematics learning using discovery learning models increased from $78.57 \%$ to $90.57 \%$. Besides, the results of research conducted by Ismah \& Sundi (2018) regarding the improvement of students' mathematics learning outcomes, the discovery learning model can 
improve student learning outcomes in mathematics, especially on set material. Furthermore, the results of research conducted by Yerimadesi, Putra, \& Ririanti (2017) which explains that student learning outcomes using the discovery learning model are significantly higher than student learning outcomes using conventional learning.

In addition, discovery learning is also chosen by researchers because through this model students can actively participate during the learning process, foster and instill an attitude of searching so that it can support the ability of students to solve problem solving, students can involve themselves directly in the process of discovery, so that it will make the knowledge gained is relatively long-lasting, motivates themselves and makes it easier in terms of expressing opinions, improving students' reasoning abilities and ability to think freely, and train students' cognitive skills in finding and solving problems. This model is a way to help students think more broadly and will influence student learning that tends to be passive in a more active direction. As a result, through this learning model, students' mathematical problem solving abilities are expected to increase along with the increase in students' understanding.

Discovery learning model is a teaching model that is arranged in such a way so that children or students can obtain previously unknown knowledge, not through notification, wherein some or all of the knowledge is discovered by themselves with the help of the teacher (Rahman \& Maarif, 2014: 36). According to (Suryosubroto, 2009: 178), the discovery learning model is a model where the teacher allows students to be able to find their information that is traditionally just told. Moreover, it requires students to play an active role in the learning process by answering various questions and solving problems to find a concept. According to Tumurun, Gusrayani, \& Jayadinata (2016: 109), the discovery learning model emphasizes student-centered learning, making students more active in learning and looking for material so that learning will be more meaningful than conventional learning models. Safrida, Ikhsan, \& Hajidin (2019: 21) stated that the discovery learning model is a learning model that assigns a child in such a way acquires knowledge that he does not yet know without being told, that partial or even the entire knowledge is found by his own. Thus, the discovery learning model is a learning model that emphasizes the concept of problem discovery that is not known or presented to students. 


\section{RESEARCH METHOD}

This type of research is experimental research. In this study, the treatment was conducted by applying the discovery learning model to find out whether this model is effective against the ability of students to solve mathematical problems in grade VII SMPN 4 Sungguminasa, Gowa Regency, or not. The research design used was a quasi-experimental design with a type of nonequivalent control group design. The study design used pretest and posttest in both groups. Hence, the results of the agreement can be acquired more accurately.

This research was conducted in two stages, namely the preparation phase and the implementation phase. At the preparatory stage, several things were carried out, namely: (a) preparing learning programs based on the curriculum, (b) preparing learning resources, and (c) developing instruments that were adapted to the material. While at the implementation stage several things were done, namely: (a) conducting initial discussions with mathematics subject teachers at SMPN 4 Sungguminasa, Gowa Regency to discuss the material to be taught, (b) providing an initial test (pretest) before applying the discovery learning model about the material taught and followed by students of class VII.A as an experimental class and class VII.C as a control class, (c) conducting learning activities in class VII.A SMPN 4 Sungguminasa Gowa Regency taught with discovery learning model and in class VII.C SMPN 4 Sungguminasa, Gowa Regency taught without the discovery learning model, (d) completing observation sheets of student and teacher activities during the learning process at each meeting, and (e) providing a final test (posttest).

This research was conducted in grade VII SMPN 4 Sungguminasa, Gowa Regency. Furthermore, the population in this study were all VII grade students of SMPN 4 Sungguminasa, Gowa Regency. The sampling technique used was purposive sampling so that samples obtained in grade VII.A as an experimental class and VII.C as a control class. The number of students in grade VII.A as many as 32 students with details of 16 female students and 16 male students. The number of students in grade VII.C is also 32 students with details of 18 female students and 14 male students.

Data collection techniques used in this study were tests and observations. The research instrument was a mathematics learning achievement test and observation sheets of student and teacher activities. Data processing research results used two statistical analysis techniques, namely descriptive statistics and inferential statistics. Inferential analysis was used to test the hypotheses that 
researchers have been formulated by first conducting a prerequisite test that was the normality test and the data homogeneity test. Testing the difference in value was only carried out on the average of the two values, and for this purpose, a technique used is t-test.

\section{RESULTS AND DISCUSSION}

The results of descriptive statistical analysis in this study provided an overview of the ability to solve mathematical problems of VII grade students of SMPN 4 Sungguminasa, Gowa Regency who were taught with discovery learning models, which can be seen in table 1 .

Table 1. Descriptive Statistics of Pretest and Posttest Results for Experimental Class

\begin{tabular}{lcc}
\hline \multirow{2}{*}{\multicolumn{1}{c}{ Statistics }} & \multicolumn{2}{c}{ Score of Grade VII.A } \\
\cline { 2 - 3 } & Pretest & Posttest \\
\hline Number of Samples & 32 & 32 \\
The lowest value & 40 & 65 \\
The highest score & 65 & 95 \\
Average value & 52,81 & 80,16 \\
Standard Deviation & 7,177 & 7,980 \\
Variance Value & 51,512 & 63,684 \\
\hline
\end{tabular}

If the students' mathematical problem solving abilities are grouped into several categories, including very low, low, medium, high, and very high, the frequency and percentage will be obtained after the pretest and posttest, which are distributed into the group categories presented in table 2.

Table 2. Frequency Distribution and Percentage of Mathematical Problem Solving Ability in Experimental Class

\begin{tabular}{cccccc}
\hline \multirow{2}{*}{ Interval } & Category & \multicolumn{2}{c}{ Pretest Experiment } & \multicolumn{2}{c}{ Posttest Experiment } \\
\cline { 3 - 6 } & Frequency & $\begin{array}{c}\text { Percentage } \\
\mathbf{( \% )}\end{array}$ & Frequency & $\begin{array}{c}\text { Percentage } \\
\mathbf{( \% )}\end{array}$ \\
\hline $\mathbf{4 0 - 4 5}$ & Very Low & 7 & 21,88 & 6 & 18,75 \\
$\mathbf{4 6 - 5 0}$ & Low & 8 & 25,00 & 7 & 21,88 \\
$\mathbf{5 1 - 5 5}$ & Medium & 10 & 31,25 & 4 & 12,50 \\
$\mathbf{5 6 - 6 0}$ & High & 3 & 9,38 & 9 & 28,13 \\
$\mathbf{6 1 - 6 5}$ & Very High & 4 & 12,50 & 6 & 18,75 \\
\hline & Total & $\mathbf{3 2}$ & $\mathbf{1 0 0}$ & & $\mathbf{3 2}$ \\
\hline
\end{tabular}


Based on table 2, it can be seen that before applying the discovery learning model, the average mathematical problem solving ability of students was 52.81 with the highest percentage of $31.25 \%$ or 10 students of the experimental class having the level of mathematical problem solving ability of students in the medium category. Whereas after applying the discovery learning model, the average mathematical problem solving ability of students became 80.16 with the highest percentage of $28.13 \%$ or 9 students of the experimental class having high levels of students' mathematical problem solving abilities. Thus, it can be seen that after applying the discovery learning model, the students' mathematical problem solving abilities have increased. The average mathematical problem solving ability of students previously with the highest percentage was in the medium category. However, after applying the discovery learning model, the average of mathematical problem solving ability of students with the highest percentage was in the high category.

It occurs due to during the learning process takes place, students are given time to work and interact in groups so that they can be able to exchange ideas and help each other. Thus, it can improve students' mathematical problem solving abilities through the delivery of their ideas and thoughts, and students can use and utilize various learning resources to solve mathematical problems such as books, teaching aids (coins and dice), and the internet. Besides, students are more motivated in learning and more creative in solving math problems that are given so that students more active in the learning process. This is in line with Salmon's opinion in Muhamad (2016) stated that in its application, the discovery learning model develops the way students learn actively by discovering themselves, investigating themselves, the results obtained will last long in the memory, as well as the teacher's position in the class as a guide and directing learning activities under the objectives of learning.

Furthermore, a description of the mathematical problem-solving abilities of VII grade students of SMPN 4 Sungguminasa, Gowa Regency taught without discovery learning model can be seen in table 3 . 
Table 3. Descriptive Statistics of Pretest and Posttest Results of Control Class

\begin{tabular}{lcc}
\multicolumn{1}{c}{ Statistics } & \multicolumn{2}{c}{ Score of Grade VIII.C } \\
& Pretest & Posttest \\
\hline Number of Samples & 32 & 32 \\
The Lowest Value & 40 & 45 \\
The Highest Score & 70 & 75 \\
Average Value & 56,41 & 61,09 \\
Standard Deviation & 7,539 & 8,494 \\
Variance Value & 56,830 & 72,152 \\
\hline
\end{tabular}

If the students' mathematical problem solving ability is grouped into several categories, including very low, low, medium, high, and very high, then the frequency and percentage are obtained after the pretest and posttest, which are distributed into the group categories presented in table 4.

Table 4. Frequency Distribution and Percentage of Mathematical Problem Solving Ability in the Control Class

\begin{tabular}{cccccc}
\hline Interval & Category & Pretest Experiment & \multicolumn{2}{c}{ Posttest Experiment } \\
& & Frequency & $\begin{array}{c}\text { Percentage } \\
(\mathbf{0})\end{array}$ & & Frequency \\
\hline $\mathbf{4 0 - 4 6}$ & Very Low & 3 & 9,38 & 6 & 18,75 \\
$\mathbf{4 7 - 5 2}$ & Low & 6 & 18,75 & 2 & 6,25 \\
$\mathbf{5 3 - 5 8}$ & Medium & 9 & 28,13 & 11 & 34,38 \\
$\mathbf{5 9}-\mathbf{6 4}$ & High & 7 & 21,88 & 4 & 12,50 \\
$\mathbf{6 5 - 7 0}$ & Very High & 7 & 21,88 & 9 & 28,13 \\
\hline & Total & $\mathbf{3 2}$ & $\mathbf{1 0 0}$ & & $\mathbf{3 2}$ \\
\hline
\end{tabular}

Based on table 4 above, it can be seen that before learning without discovery learning model, the average mathematical problem solving ability of students was 56.41 with the highest percentage of $28.13 \%$ or 9 students of the control class had a level of mathematical problem solving ability students in the medium category. Meanwhile, after learning without applying the discovery learning model, the average mathematical problem solving ability of students becomes 80.16 , with the highest percentage of $34.38 \%$ or 11 control class students having the level of students' mathematical problem solving abilities in the medium category. This result is different from the experimental class, which is the level of students' mathematical problem solving ability before learning in the medium category and after learning in the high category. Thus, it can be 
inferred that after learning without the discovery learning model applied, the students' mathematical problem solving abilities did not experience an increase in the previous average mathematical problem solving ability of students, the highest percentage was in the medium category. However, after the discovery learning model was applied, the average solving ability the highest percentage of students' mathematical problems remained in the medium category. This is because during the learning process took place; only a few students were active in learning. Students who did not understand the material were just passive, and some even told stories with their peers so that learning became ineffective.

The results of inferential statistical analysis in this study were used to test the research hypotheses that were preceded by conducting a prerequisite test that is the normality test that was analyzed using the Kolmogorov-Smirnov test and the homogeneity test analyzed using the F test. Mathematics students in the control class and experimental class were normally distributed and homogeneous.

Hypothesis testing uses an independent sample t-test. Based on the results of the posttest data analysis of the two groups, it can be concluded that Ho is rejected. This means that there are differences in the ability to solve mathematical problems between grade VII students of SMPN 4 Sungguminasa, Gowa Regency, who were taught by applying the discovery learning model and VII Grade students of SMPN 4 Sungguminasa, Gowa Regency who were taught without using the discovery learning model.

Refers to the results of the analysis obtained and strengthened by the findings of previous studies conducted by Simanjuntak, Napitupulu, Manullang, Manalu, \& Sinambela (2018) under the title "The Enhancement Difference of Student Mathematical Problem Solving Ability between Guided Discovery Learning Model and Direct Learning Model". They stated that: (1) there are differences in the mathematical problem solving abilities of students taught with discovery learning models and direct learning models, (2) mathematical problem solving abilities of students taught with discovery learning model were higher than direct learning model. Therefore it can be concluded that the discovery learning model can improve students' mathematical problem solving ability compared to the learning model without the discovery learning model. The results of this study also contradicted the results of research conducted by Putri, Gunowibowo, \& Coesamin (2017) entitled "The Effectiveness of the Discovery Learning Method in Terms of Students 'Mathematical Problem Solving 
Capabilities" explains that discovery learning is not effective in terms of students' mathematical problem solving abilities.

In accordance with the effectiveness test, it was found that learning with discovery learning model was effective on students' mathematical problem solving abilities. This is also supported by previous research conducted by Hulukati, Zakiyah, \& Rustam (2018) entitled The Effect of Guided Discovery Learning Model with Super item Test on Students' Problem-Solving Ability in Mathematics, cited that the discovery learning model is more effective than the cooperative learning model in improving the ability to solve mathematical problems. Also, research conducted by Yuliana, Tasari, \& Wijayanti (2017) concluded that discovery learning is better than conventional models. It means that the discovery learning model is better than the conventional learning model.

Several factors cause the discovery learning model better than the conventional model. Some of the reasons were that the students are more active when learning with the discovery learning model because the method is considered new by students and is different from conventional learning. Some students are more active when learning took place with the discovery learning model, although not all students did actively participate than the conventional model.

\section{CONCLUSION}

Based on the analysis, the average pretest score of students in the experimental class was 52.81, and after applying the discovery learning model, the average score of students was 80.16 with a standard deviation of 7.980. In the pretest score, most of the students' scores were in the medium category $(31.25 \%)$, and the highest posttest score was in the high category $(28.13 \%)$. It was found that the application of learning discovery models to students' mathematical problem solving abilities is effective. So, it is recommended to use discovery learning models, especially to improve the ability to solve mathematical problems.

\section{REFERENCES}

Akbar, P., Hamid, A., Bernard, M., \& Sugandi, A. I. (2018). Analisis kemampuan pemecahan masalah dan disposisi matematik siswa kelas XI SMA Putra Juang dalam materi peluang. Jurnal Cendekia: Jurnal Pendidikan Matematika, 2(1), 144-153. https:// doi.org/10.31004/cendekia.v2i1.62. 
Fahmi, N., Sinaga, B., \& Rajagukguk, W. (2019). Analysis of students metacognitive ability in mathematical problem solving in SMP Negeri 4 Bendahara Aceh Tamiang. American Journal of Educational Research, 7(2), 166-169. Retrieved from http:/ / article.scieducationalresearch.com/pdf/ education-7-2-8.pdf.

Hidayat, A. S. (2011). Efektivitas pembelajaran matematika menggunakan metode kooperatif tipe think pair share (TPS) dengan pendekatan contextual teaching and learning (CTL) terhadap keaktifan belajar dan komunikasi matematis siswa SMP (UIN Sunan Kalijaga Yogyakarta). Retrieved from http:// digilib.uin-suka.ac.id/7694/.

Hulukati, E., Zakiyah, S., \& Rustam, A. (2018). The effect of guided discovery learning model with superitem test on students' problem-solving ability in mathematics. Journal of Social Science Studies, 5(2), 210-219. https:// doi.org/10.5296/jsss.v5i2.13406.

Ismah, \& Sundi, V. H. (2018). Penerapan model discovery learning untuk meningkatkan hasil belajar matematika siswa kelas VII SMP Labschool Fip UMJ. FIBONACCI: Jurnal Pendidikan Matematika dan Matematika, 4(2), 161-169. https:// doi.org/10.24853/fbc.4.2.65-73.

Ketonen, E. E., Dietrich, J., Moeller, J., Salmela-Aro, K., \& Lonka, K. (2018). The role of daily autonomous and controlled educational goals in students' academic emotion states: An experience sampling method approach. Learning and Instruction, 53, 10-20. https://doi.org/10.1016/ j.learninstruc.2017.07.003.

Muhamad, N. (2016). Pengaruh metode discovery learning untuk meningkatkan representasi matematis dan percaya diri siswa. Jurnal Pendidikan UNIGA, 10(1), 9-22. Retrieved from http://journal.uniga. ac.id/index.php/JP/article/view/83.

Mustofa, B. (2015). Psikologi Pendidikan. Yogyakarta: Parama Ilmu.

Priya, J. J. (2017). Mathematical problem solving ability of eleventh standard students. Journal on Educational Psychology, 11(2), 36-44. Retrieved from https:/ / files.eric.ed.gov/fulltext/EJ1169548.pdf.

Putri, D. A., Gunowibowo, P., \& Coesamin, M. (2017). Efektivitas metode discovery learning ditinjau dari kemampuan pemecahan masalah matematis siswa. Jurnal Pendidikan Matematika Unila, 5(3). Retrieved from http://jurnal.fkip.unila.ac.id/index.php/MTK/article/view/12457.

Rahman, A., \& Ahmar, A. S. (2016). Exploration of mathematics problem solving process based on the thinking level of students in junior high school. International Journal of Environmental E Science Education, 11(14), 72787285. Retrieved from http:/ / www.ijese.net/makale/998.html.

Rahman, R., \& Maarif, S. (2014). Pengaruh penggunaan metode discovery terhadap kemampuan analogis matematis siswa SMK Al-Ikhsan Pamarican Kabupaten Ciamis Jawa Barat. Jurnal Ilmiah Program Studi 
Matematika STKIP Siliwangi, 3(1), 33-58. https://doi.org/10.22460/ infinity.v3i1.p33-58.

Safrida, Ikhsan, M., \& Hajidin. (2019). The implementation of discovery learning model to improve students' mathematical reasoning skill. International Journal of Sciences: Basic and Applied Research (IJSBAR), 44(2), 19-25. Retrieved from https://gssrr.org/index.php/JournalOfBasicAndAppli ed/article/view/9780.

Sanjaya, W. (2017). Strategi pembelajaran edisi 1 (Cetakan Ke). Jakarta.

Sarnawiah, \& Yensy, N. A. (2019). Meningkatkan hasil belajar matematika peserta didik kelas VIII-2 SMP Negeri 3 Kota Bengkulu melalui model discovery learning (DL). Jurnal Pendidikan Matematika Raflesia, 4(2), 47-57. https://doi.org/10.33449/jpmr.v4i2.9752.

Shaikh, B., \& Daudpota, S. M. (2019). Exploring the impact of mathematics perception on students' performance. Sukkur IBA Journal of Computing and Mathematical Sciences, 3(1), 17-27. https://doi.org/10.30537/sjcms. v3i1.369.

Simamora, R. E., Saragih, S., \& Siregar, H. (2019). Improving students' mathematical problem solving ability and self-efficacy through guided discovery learning in local culture context. International Electronic Journal of Mathematics Education, 14(1), 61-72. https://doi.org/10.12973/iejme/ 3966.

Simanjuntak, D., Napitupulu, E. E., Manullang, M., Manalu, R., \& Sinambela, L. (2018). The enhancement difference of student mathematical problem solving ability between guided discovery learning model and direct learning model. American Journal of Educational Research, 6(12), 1688-1692. https://doi.org/10.12691/EDUCATION-6-12-15.

Sitinjak, M. F. B., Murni, A., \& Hutapea, N. M. (2016). Penerapan discovery learning untuk meningkatkan hasil belajar matematika siswa kelas VIIIB SMP Beer Seba Pekanbaru. Jurnal Online Mahasiswa Fakultas Keguruan dan Ilmu Pendidikan, 3(2). Retrieved from https://jom.unri.ac.id/index.php/ JOMFKIP/article/view/11772.

Suryosubroto. (2009). Proses belajar mengajar di sekolah: Wawasan baru, beberapa metode pendukung, dan beberapa komponen layanan khusus. Jakarta: Rineka Cipta.

Susanto. (2013). Teori belajar dan pembelajaran di sekolah dasar. Jakarta: Kencana. Tirtarahardja, U. (2010). Pengantar pendidikan. Makassar: UNM Press.

Tumurun, S. W., Gusrayani, D., \& Jayadinata, A. K. (2016). Pengaruh model pembelajaran discovery learning terhadap keterampilan berpikir kreatif siswa pada materi sifat-sifat cahaya. Jurnal Pena Ilmiah, 1(1), 101-110. https://doi.org/10.23819/pi.v1i1.2936.

Uno, H. (2008). Belajar dengan pendekatan paikem. Jakarta: PT. Bumi Aksara.

Utami, R. W., \& Wutsqa, D. U. (2017). Analisis kemampuan pemecahan masalah 
matematika dan self-efficacy siswa SMP negeri di Kabupaten Ciamis. Jurnal Riset Pendidikan Matematika, 4(2), 166-175. https://doi.org/ 10.21831/jrpm.v4i2.14897.

Yerimadesi, Y., Putra, A., \& Ririanti, R. (2017). Efektivitas penggunaan modul larutan penyangga berbasis discovery learning terhadap hasil belajar siswa kelas XI MIA SMAN 7 Padang. Jurnal Eksakta Pendidikan (JEP), 1(1), 17-23. https://doi.org/10.24036/jep/vol1-iss1/29.

Yuliana, Y., Tasari, T., \& Wijayanti, S. (2017). The effectiveness of guided discovery learning to teach integral calculus for the mathematics students Of mathematics education Widya Dharma University. Infinity Journal, 6(1), 01-10. https://doi.org/10.22460/infinity.v6i1.p01-10. 